\title{
Application Development Design "How To Make Money Online” Using The Wartefall Method (Case Study : CV Satoeasa For Indonesia)
}

\section{Rancangan Pengembangan Aplikasi "How To Make Money Online" Menggunakan Metode Waterfall (Studi Kasus: CV Satoeasa Untuk Indonesia)}

\author{
Agil Setyo Prasandi ${ }^{1}$, Tikaridha Hardiani ${ }^{2}$ \\ \{ agilsandi38@gmail.com ${ }^{1}$, tikaridha@unisayogya.ac.id ${ }^{2}$ \} \\ Program Studi Teknologi Informasi ${ }^{1}$ \\ Fakultas Sains dan Teknologi \\ Universitas 'Aisyiyah Yogyakarta \\ Mlangi Nogotirto, Jl. Siliwangi Jl. Ringroad Barat No.63, Nogotirto, Kec. Gamping, Kabupaten Sleman, Daerah \\ Istimewa Yogyakarta 55592
}

\begin{abstract}
CV Satoeasa is a organization engaged in training and consulting services in the context of empowering and developing business actors. Satoeasa is supported by personnel who have competency standards and experience in the fields of entrepreneurship and local economic development. CV Satoeasa Untuk Indonesia is committed to increasing entrepreneurial capacity and is passionate about realizing a growing and developing business. use of the application "How To Make Money Online" to increase competitiveness with other companies, improve the quality of service to customers because now customers have more options to browse applications, compare and analyze services and ratings before choosing an application to be installed on their phone device. For the development of the application "How To Make Money Online" CV Satoeasa For Indonesia plans to create a web-based application with the aim of making it easier for customers to access it without having to install their personal device first. This research uses the waterfall method. In the waterfall method there are several steps including requirements, design, implementation, verification and maintenance. This "How To Make Money Online" application is still based on Android, therefore the author intends to make a web-based "How To Make Money Online" application development design. The result of this research is an application development design. Application development is easier with the application design that will be developed. The conclusion is the "How To Make Money Online" application development design using HTML (HyperText Markup Language) programming. Before this application was developed, it was based on Android and after it was developed it became web-based. In this application there are several menus including the homepage, articles, contacts, about us and help. Provide solutions to CV Satoeasa Untuk Indonesia regarding the design of the application development "How To Make Money Online" using the waterfall method
\end{abstract}

Keywords - application, waterfall, application design

Abstrak. CV Satoeasa adalah lembaga yang bergerak di bidang konsultasi dan jasa konsultasi dalam rangka pengembangan dan pemberdayaan sumber pelaku usaha. Personel yang memiliki standar kompetensi yang baik dan berpengalaman dibidangnya turut mendukung Satoeasa dalam meningkatkan ekonomi lokal. CV Satoeasa Untuk Indonesia berkomitmen dalam peningkatan kapasitas wirausaha dan bersemangat dalam mewujudkan bisnis yang tumbuh dan berkembang. kegunaan aplikasi "How To Make Money Online” untuk meningkatkan daya saing dengan perusahaan yang lain, meningkatkan kualitas pelayanan terhadap pelanggan karena sekarang pelanggan memiliki lebih banyak opsi untuk menelusuri aplikasi, membandingkan dan menganalisis layanan maupun rating sebelum memilih suatu aplikasi untuk dipasang pada perangkat telepon mereka. Untuk pengembangan apikasi "How To Make Money Online" CV Satoeasa Untuk Indonesia ini menggunakan metode waterfall. Di dalam metode waterfall terdapat beberapa langkah diantaranya yaitu requirenment, desain, implementation, verification dan maintenance. Aplikasi "How To Make Money Online" ini masih berbasis android oleh karena itu penulis bermaksud membuat rancangan pengembangan aplikasi "How To Make Money Online" berbasis web. hasil dari uji coba yaitu pengujian dilakukan pada aspek fungsionalitas kepada sistem analis, administrator dan pengguna aplikasi langsung. Hasil dari penelitian ini adalah rancangan pengembangan aplikasi. Pengembangan aplikasi lebih mudah dengan adanya rancang bangun aplikasi yang akan dikembangkan. Kesimpulannya adalah Rancangan pengembangan aplikasi "How To Make Money Online" menggunakan pemrograman HTML (HyperText Markup Language). Sebelum dikembangkan aplikasi ini berbasis android dan setelah dikembangkan menjadi berbasis web. Di dalam aplikasi ini terdapat beberapa menu diantaranya yaitu beranda, artikel, kontak, tentang kami dan bantuan. Memberikan solusi kepada CV Satoeasa Untuk Indonesia mengenai rancangan pengembangan aplikasi "How To Make Money Online" dengan menggunakan metode waterfall

Kata Kunci - aplikasi, waterfall, rancang bangun 


\section{Pendahuluan}

Teknologi informasi komputer pada saat ini berkembang dengan sangat cepat dan pesat. Hal ini berkaitan dengan kegiatan yang sering dilakukan manusia yang biasanya dilakukan secara manual, kini akan semakin lebih cepat jika dilakukan dengan bantuan mesin yaitu teknologi komputer. Pengembangan teknologi informasi telah banyak menghasilkan sistem dan aplikasi yang sangat bermanfaat. Salah satu aplikasinya adalah internet. Internet yang populer sering disebut perangkat lunak berbasis web yang telah berkembang pesat baik dari segi penggunaan, dan kompleksitasnya. Aplikasi web mulanya hanya berupa situs yang bersifat statis tetapi saat ini telah banyak yang bersifat dinamis dan interaktif yang digunakan dalam sistem informasi.[1]

Kemajuan teknologi informasi dan teknologi komputer tersebut mengakibatkan semakin berkembangnya pemahaman manusia tentang pentingnya aspek teknologi dalam suatu perusahaan, instansi, atau organisasi. Sistem informasi memiliki suatu data yang terorganisasi beserta tata cara penggunaannya yang mencakup penyajian datanya. Sistem informasi merupakan suatu sistem terintegrasi yang mampu menyediakan informasi yang berguna bagi penggunanya[1]. Perkembangan teknologi yang sangat pesat menimbulkan efek dari cara kerja pribadi maupun organisasi, terlebih dalam dunia bisnis. Teknologi dapat membantu perkembangan bisnis dikarenakan dengan teknologi dapat memangkas pengeluaran yang cukup banyak. Manfaat teknologi yaitu sebagai alat untuk memantau kegiatan yang terjadi dalam bisnis diantaranya transaksi penjualan dan memantau stok barang dagangan yang masih tersedia[2].

Aplikasi web banyak digunakan sebagai media untuk mencari informasi dan komunikasi dalam dunia keuangan, bisnis, dan jasa serta merambah dunia pendidikan. Aplikasi berbasis web adalah aplikasi yang dibuat menggunakan bahasa pemrograman HTML, PHP, CSS, JS yang memerlukan web server dan browser untuk menjalankannya. ciri utama yang membuat aplikasi berbasis lebih diminati dan lebih mudah diimplementasikan dikehidupan sehari-hari yaitu aplikasi berbasis web dapat berjalan pada jaringan internet maupun intranet (Jaringan LAN), Data terpusat dan kemudahan dalam mengaksesnya. Aplikasi berbasis web menjadi terkenal karena kemudahan klien untuk mengaksesnya. menginstalasi perangkat lunak pada kemungkinan ribuan komputer klien dan kemampuan untuk memelihara dan memperbaiki aplikasi web tanpa harus mendistribusikan merupakan alasan kunci popularitasnya. Aplikasi web yang umum misalnya webmail, toko ritel daring, lelang daring, wiki, papan diskusi, weblog, serta MMORPG (Massively Multiplayer Online Role-Playing Game).[3]

Dalam era milenial ini perkembangan teknologi memiliki pengaruh yang besar dalam kehidupan masyarakat maka dari itu masyarakat harus memanfaatkan perkembangan teknologi tersebut untuk mempermudah penyelesaian berbagai pekerjaan mereka. Melalui pendidikan manusia akan menjadi tahu dari yang mereka tidak ketahui akan tetapi tidak semua masyarakat dapat mengenyam pendidikan ditingkat yang sama karena keterbatasan ekonomi. Dengan alasan diatas maka penelitian ini berjudul pengembangan aplikasi "How To Make Money Online" yang dimiliki oleh CV Satoeasa Untuk Indonesia. Aplikasi "How To Make Money Online" ini masih berbasis android oleh karena itu penulis bermaksud membuat rancangan pengembangan aplikasi "How To Make Money Online” berbasis web. Satoeasa adalah lembaga profesional yang bergerak di bidang jasa pelatihan dan konsultasi dalam rangka pemberdayaan dan pengembangan sumber pelaku usaha. Personel yang memiliki standar kompetensi yang baik dan berpengalaman dibidangnya turut mendukung Satoeasa dalam meningkatkan ekonomi lokal. [4]

\section{METODE}

\section{II.I Metode Pengumpulan Data}

Metode yang digunakan untuk pengumpulan data ada 2 metode yaitu;

1. Studi Pustaka yaitu mencari referensi lain yang berkaitan dengan rancangan pengembangan aplikasi berbasis web. Studi Pustaka adalah kegiatan mencari, membaca dan mencatat data pustaka serta mengolah data tersebut sebagai bahan penelitian.[5]

2. Metode survey (observasi) adalah penelitian yang diadakan untuk memperoleh fakta dari gejala yang ada dan mencari informasi secara faktual[6]

\section{II.II Metode Pengolahan Data}

Metode yang digunakan untuk pengolahan data yaitu metode Waterfall. Metode Waterfall adalah sebuah metode pengembangan perangkat lunak yang berurutan dengan melalui tahap perencanaan, pemodelan dan 
Procedia of Engineering and Life Science Vol. 1. No. 2 Juni 2021

Seminar Nasional \& Call Paper Fakultas Sains dan Teknologi (SENASAINS 2nd)

Universitas Muhammadiyah Sidoarjo

implementasi serta pengujian. Proses pengembangan perangkat lunak yang mengalir ke bawah seperti air terjun.[7]

Metode waterfall memiliki beberapa tahapan seperti; analisis kebutuhan, desain sistem, pemrograman dan uji coba, penerapan program dan pemeliharaan.[8] Tahapan dari metode waterfall dapat dilihat pada gambar 1.

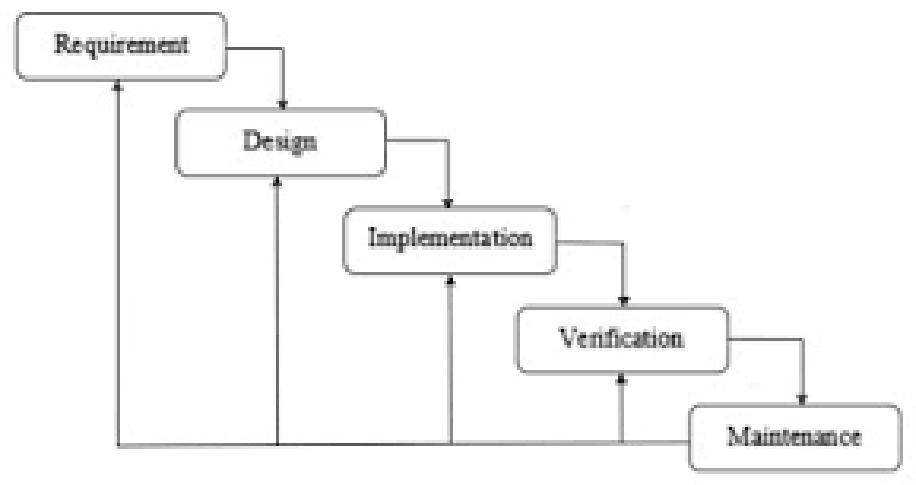

Requirenment

Gambar 1. Waterfall Diagram

Proses pengumpulan data kebutuhan perangkat lunak melalui konsultasi dengan pengguna. Proses mencari permasalahan yang ada di dalam aplikasi. Proses ini menjabarkan mengenai fungsi-fungsi dan tujuan dari perangkat lunak sebagai spesifikasi aplikasi yang akan dibuat.

Design

Pada tahap ini difokuskan pada struktur data, arsitektur perangkat lunak, representasi antarmuka dan detail procedural. Struktur data adalah representasi dari hubungan antara elemen-elemen data individual.

Implementation

Proses membangun perangkat lunak yang direalisasikan sebagai rangkaian program. Selanjutnya pengujian unit melibatkan verifikasi bahsa setiap unit program telah memenuhi spesifikasinya.

Verification

Unit yang telah dikembangkan di tahap implementasi kemudian diintegrasikan ke dalam sistem pengujian masing-masing unit.

Maintenance

Tahapan terakhir dalam metode waterfall. Setelah perangkat lunak lolos dalam pengujian verifikasi selanjutnya akan masuk ke dalam tahap pemeliharaan yaitu memperbaiki kesalahan yang tidak ditemukan pada langkah sebelumnya.

\section{Hasil Dan Pembahasan}

\section{Pengembangan Aplikasi “How To Make Money Online”}

Tahapan dari metode waterfall dijelaskan pada Tabel 1.

\begin{tabular}{|c|c|c|}
\hline No & Tahap & Hasil \\
\hline 1. & Requirenment & $\begin{array}{l}\text { 1. Aplikasi "How To Make Money Online" berbasis android } \\
\text { kurang fleksibel. } \\
\text { 2. Aplikasi "How To Make Money Online" berbasis android } \\
\text { penggunanya sedikit. } \\
\text { 3. Aplikasi "How To Make Money Online" berbasis android } \\
\text { pengembangannya lebih susah dibandingkan dengan } \\
\text { aplikasi berbasis web. }\end{array}$ \\
\hline
\end{tabular}


3.

4.

5.

Maintenance
Aplikasi yang akan dibuat menggunakan bahasa pemrograman HTML (HyperText Markup Language).

Pengujian dilakukan pada aspek fungsionalitas kepada sistem analis, administrator dan pengguna aplikasi langsung.

Pemeliharaan dilakukan apabila aplikasi mengalami kesalahan yang tidak terdeteksi di tahap verification.

Tabel 1. Tahapan metode waterfall

Work breakdown structure yaitu metode yang digunakan untuk mempermudah memecahkan masalah. WBS digunakan untuk melakukan Breakdown atau memecahkan tiap proses pekerjaan menjadi lebih detail.hal ini dimaksudkan agar proses perencanaan proyek memiliki tingkat yang lebih baik.[9]

Desain Work Breakdown Structur ditunjukkan pada Gambar 2.

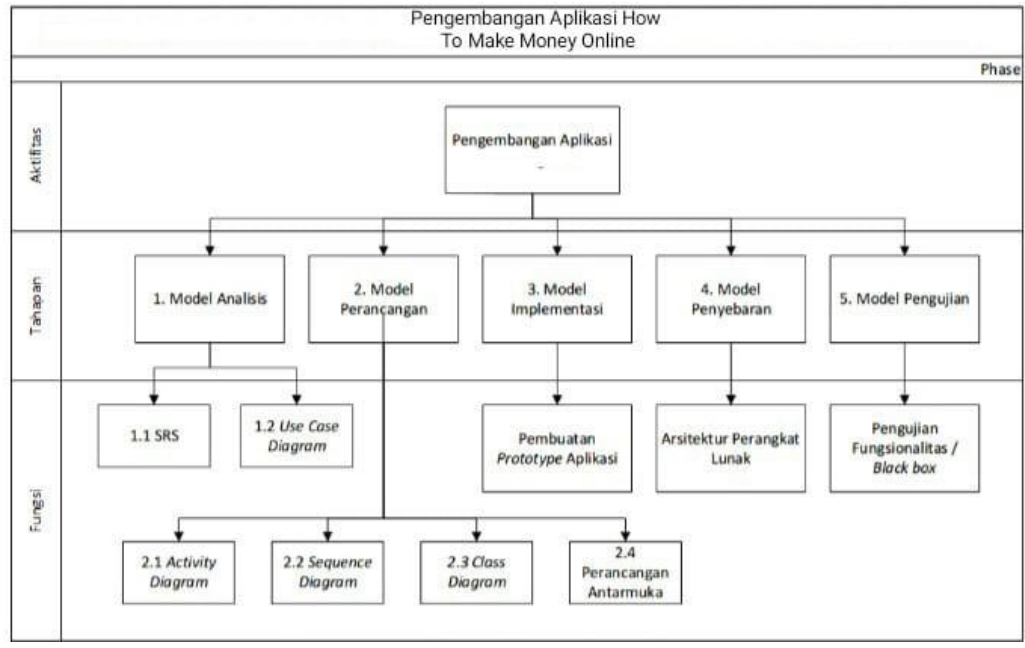

Gambar 2. Work Breakdown Structure

1. Pada tahapan model analisis akan dilakukan kegiatan mengumpulkan informasi atau data kebutuhan sebagai acuan untuk melakukan pengembangan aplikasi. Pada tahap ini terdapat 2 elemen yaitu SRS dan Use Case Diagram.

SRS (Software Requirement Specification) adalah file dokumen yang menjelaskan mengenai berbagai kebutuhan yang harus dipenuhi oleh suatu software.

Use Case Diagram adalah gambaran dari interaksi yang terjadi antara sistem dan lingkungannya.

2. Pada tahap model perancangan akan dilakukan kegiatan merancang Activity Diagram, Sequence Diagram, Class Diagram dan Perancangan Antarmuka.

3. Tahapan model implementasi adalah tahapan yang paling penting diantara tahapan lainnya karena didalam tahapan ini akan dilakukan kegiatan pembuatan prototype aplikasi. 
Procedia of Engineering and Life Science Vol. 1. No. 2 Juni 2021

Seminar Nasional \& Call Paper Fakultas Sains dan Teknologi (SENASAINS 2nd)

Universitas Muhammadiyah Sidoarjo

4. Tahapan model penyebaran merupakan tahapan pembuatan arsitektur perangkat lunak. Arsitektur merujuk ke tiga arsitektur yang didefinisikan yaitu: arsitektur data, arsitektur aplikasi, dan arsitektur teknologi.[10]

5. Tahapan model pengujian merupakan tahapan terakhir dalam pengembangan aplikasi, biasanya tahapan ini dilakukan pengujian fungsionalitas.

Desain Sistem Aplikasi

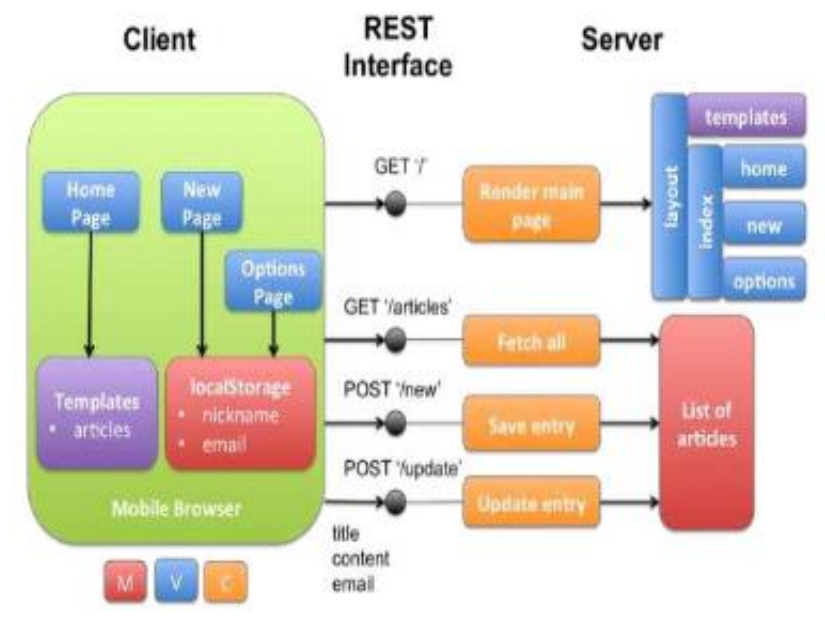

Gambar 3. Desain Sistem Aplikasi

Pada Gambar 3 di atas dapat dijelaskan arsitektur desain dari aplikasi "How To Make Money Online" berbasis web. Dimana aplikasi terdiri dari kebutuhan Home page yang terdiri dari interface artikel. Semua bisa diakses via mobile. PC dan gadget. Di dalam aplikasi terdapat beberapa menu diantaranya yaitu;

1. Beranda

Tampilan awal sebuah aplikasi

berbasis web.

2. Artikel

Menu ini menampilkan beberapa artikel mengenai how to make money online

3. Kontak

Menu ini berisi kontak person yang bisa dihubungi oleh pelanggan untuk konsultasi bisnis atau keperluan lainnya.

4. Bantuan

Menu bantuan berisi petunjuk penggunaan aplikasi. Jika pengguna aplikasi mengalami kendala dalam menggunakan aplikasi, pengguna dapat membuka menu bantuan ini.

5. Notifikasi

Menu notifikasi ini berisi pemberitahuan mengenai artikel terbaru yang diupload oleh developer.

6. Tentang kami

Menu tentang kami berisi penjelasan singkat mengenai CV Satoeasa Untuk Indonesia.

Web server adalah server internet yang melayani permintaan web dari klien dengan menggunakan HTTP (HyperText Transfer Protocol) untuk melayani semua proses pentransferan data yang diminta oleh klien menuju middleware, dan respon dari middleware akan dikirimkan kembali pada klien yang meminta data.

Aplikasi berbasis web merupakan perangkat lunak yang diakses menggunakan internet dengan memakai web browser. Aplikasi web dibangun hanya dengan menggunakan bahasa markah yang disebut HTML (Hyper Text Markup Langauge). Pada perkembangan berikutnya, sejumlah skrip dan objek dikembangkan untuk memperluas kemampuan HTML seperti PHP dan ASP pada skrip dan Apllet pada objek.

Tampilan aplikasi “How To Make Money Online” berbasis android ditunjukan pada Gambar 4. 
Procedia of Engineering and Life Science Vol. 1. No. 2 Juni 2021

Seminar Nasional \& Call Paper Fakultas Sains dan Teknologi (SENASAINS 2nd)

Universitas Muhammadiyah Sidoarjo

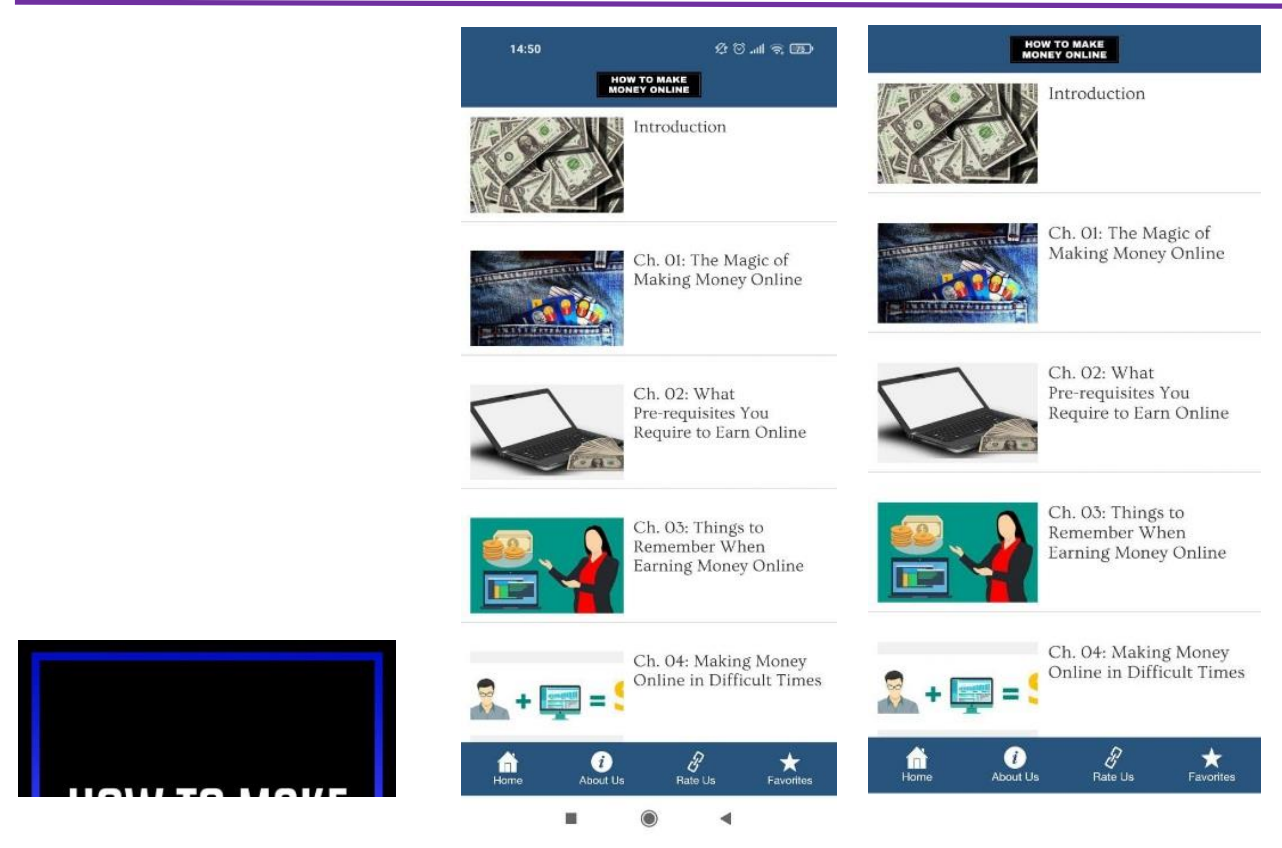

Gambar 4. Tampilan aplikasi “How To Make Money Online” berbasis android

Aplikasi "How to make money online" adalah sebuah aplikasi berbasis android, aplikasi ini dibuat dengan tujuan mempermudah para pemula yang memiliki kemauan untuk belajar mendalami bisnis terutama didunia online.

Contoh desain user interface aplikasi web "How to make money online” ditunjukkan pada Gambar 5.

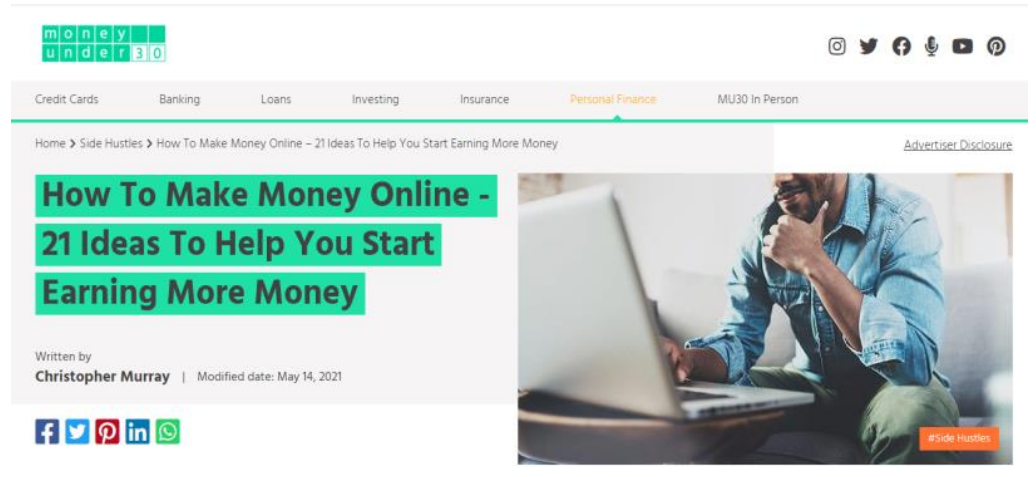

Gambar 5. Aplikasi "How to make money online"

Aplikasi yang dikembangkan terkoordinasi dengan baik yang terintegrasi pada sebuah web hosting dimana penulis mengimplementasikan aplikasi berbasis web ini secara online untuk memudahkan ujicoba aplikasi. Uji coba aplikasi bertujuan untuk mengetahui apakah aplikasi yang dikembangkan berjalan dengan baik atau masih ada kendala. Uji coba dilakukan dengan cara membuka web yang isinya aplikasi "How To Make Money Online" apakah bisa dibuka atau tidak.

\section{KESIMPULAN}

Kesimpulan yang dapat diambil setelah dilakukan penelitian ini adalah sebagai berikut :

1. Rancangan pengembangan aplikasi "How To Make Money Online" menggunakan pemrograman HTML (HyperText Markup Language). Sebelum dikembangkan aplikasi ini berbasis android dan setelah 
dikembangkan menjadi berbasis web. Di dalam aplikasi ini terdapat beberapa menu diantaranya yaitu beranda, artikel, kontak, tentang kami dan bantuan.

2. Memberikan solusi kepada CV Satoeasa Untuk Indonesia mengenai rancangan pengembangan aplikasi

"How To Make Money Online” dengan menggunakan metode waterfall.

\section{UCAPAN TERIMA KASIH}

Puji dan syukur atas kehadirat Allah SWT yang telah memberikan rahmat dan karunia-Nya, sehingga saya dapat menyelesaikan Jurnal yang berjudul berjudul "Rancangan Pengembangan Aplikasi "How To Make Money Online" Menggunakan Metode Waterfall di CV Satoeasa Untuk Indonesia” dengan baik. Saya ucapkan terima kasih kepada ;

1. Ibu Tikaridha Hardiani, S.Kom., M.Eng. selaku Dosen Pembimbing praktek kerja lapangan yang telah memberikan bimbingan dan arahan kepada saya selama kegiatan praktek kerja lapangan.

2. Bapak Imam Syafi'I selaku CEO CV Satoeasa Untuk Indonesia sekaligus pembimbing lapangan yang telah memberikan kesempatan kepada saya untuk melaksanakan praktek kerja lapangan.

\section{REFERENSI}

[1] R. Harisca, A. Huda, and L. Slamet, "PENGEMBANGAN SISTEM INFORMASI KEPEGAWAIAN BERBASIS WEB PADA MAN 1 PADANG," vol. 5, no. 2, p. 11, 2017.

[2] A. Hendini, "JURNAL KHATULISTIWA INFORMATIKA, VOL. IV, NO. 2 DESEMBER 2016," no. 2, p. 10, 2016.

[3] P. E. Mountaines, K. I. Satoto, and R. Kridalukmana, "Pengembangan Aplikasi Berbasis Web untuk Menampilkan Absensi dan Nilai Akhir Peserta Didik (Studi Kasus di SMP Negeri 32 Semarang), J. Teknol. Dan Sist. Komput., vol. 1, no. 4, pp. 129-144, Oct. 2013, doi: 10.14710/jtsiskom.1.4.2013.129-144.

[4] "Jasa Konsultasi Bisnis Satoeasa.html."

[5] S. Supriyadi, "Community of Practitioners: Solusi Alternatif Berbagi Pengetahuan antar Pustakawan," Lentera Pustaka J. Kaji. Ilmu Perpust. Inf. Dan Kearsipan, vol. 2, no. 2, p. 83, Feb. 2017, doi: 10.14710/lenpust.v2i2.13476.

[6] Y. Afiyanti, "Focus Group Discussion (Diskusi Kelompok Terfokus) sebagai Metode Pengumpulan Data Penelitian Kualitatif," J. Keperawatan Indones., vol. 12, no. 1, pp. 58-62, Mar. 2008, doi: 10.7454/jki.v12i1.201.

[7] A. Amrin, M. D. Larasati, and I. Satriadi, "Model Waterfall Untuk Pengembangan Sistem Informasi Pengolahan Nilai Pada SMP Kartika XI-3 Jakarta Timur,” J. Tek. Komput., vol. 6, no. 1, pp. 135-140, Jan. 2020, doi: 10.31294/jtk.v6i1.6884.

[8] G. W. Sasmito, "Penerapan Metode Waterfall Pada Desain Sistem Informasi Geografis Industri Kabupaten Tegal," J. Inform., vol. 2, no. 1, p. 7, 2017.

[9] S. Rahayu, M. Argien, and Sekolah Tinggi Teknologi Garut, "Rancang Bangun Aplikasi Penjualan Online Jaket Oscar di Toko Glacer Jacket Garut Berbasis Web," J. Algoritma, vol. 13, no. 2, pp. 341-347, Feb. 2017, doi: 10.33364/algoritma/v.13-2.341.

[10] B. Subaeki, "PERANCANGAN ARSITEKTUR SISTEM INFORMASI MENGGUNAKAN METODE ENTERPRISE ARCHITECTURE PLANNING,” p. 13. 